\title{
From civic group to advocacy coalition: Using a food policy audit as a tool for change
}

\author{
Jill K. Clark * \\ Ohio State University
}

Submitted May 25, 2017 / Revised August 8 and October 16, 2017 / Accepted October 17, 2017 /

Published online February 20, 2018

Citation: Clark, J. K. (2018). From civic group to advocacy coalition: Using a food policy audit as a tool for change. Journal of Agriculture, Food Systems, and Community Development, 8(1), 21-38. https://doi.org/10.5304/jafscd.2018.081.004

Copyright (C) 2018 by the Authors. Published by the Lyson Center for Civic Agriculture and Food Systems. Open access under CC BY license.

\begin{abstract}
'Food democracy' suggests that building a policy environment within which a community food system can thrive relies on a politically engaged citizenry. Across North America, civic-oriented groups are conducting grass-roots projects to develop community food systems. Projects are addressing issues such as local food security, healthy food access, and agriculture economic development. Local governments are paying increasing attention to this new policy arena; however, policy environments that support these
\end{abstract}

* Jill K. Clark, John Glenn School of Public Affairs, Ohio State University; 1810 College Road; Columbus, Ohio 43210 USA; +1-614-688-5984; clark.1099@,osu.edu

\section{Disclosure}

This research was made possible through a grant from Global Food Security, Agriculture and Food Research Initiative, National Institute of Food and Agriculture, United States Department of Agriculture \#2012-68007-19894. projects are often lacking. Using the advocacy coalition framework (ACF), this paper presents the case of Franklin County, Ohio to illustrate how a civically-oriented group transitioned into an advocacy coalition. A food policy audit was used as a tool to develop technical knowledge that translated the Franklin County Local Food Council's mission and objectives to political asks, resulting in a policy agenda. Through the audit process, the council identified and secured additional coalition members and increased the local governance capacity to create a healthy food policy environment. The ACF provides evidence-based framework that can be used elsewhere to evaluate the policy readiness of an FPC. Further, from a practical standpoint, I further the discussion about the utility of a local food policy audit.

\section{Keywords}

Advocacy Coalition Framework; Food Policy

Council; Food Policy Audit 


\section{Introduction}

Food policy is a relatively new issue area for local governments in the United States. When experimentation occurs in new policy areas, new forms of governance emerge, namely local partnerships between governments, local institutions, community organizations, and private businesses (Mendes, 2008). As such, Renting, Schermer, and Rossi (2012) argue that the role of civil society in food system governance is increasing in significance. One form of governance that is increasing in the U.S. is the food policy council (FPC). ${ }^{1}$ The number of FPCs in the U.S. increased from 50 in 2000 to 262 in 2016 (Scherb, Palmer, Frattaroli, \& Pollack, 2012; Sussman \& Bassarab, 2017).

FPCs convene actors from across the food system (e.g., production, processing, distribution, retailing) and across sectors (e.g., private for profit and nonprofit, community, government actors). Taking many forms, from loose coalitions to nonprofits to government task forces, FPCs foster coordination among activities in the food system, serve as forums for discussing community food issues, set local food policy agendas, and support, or start, projects and programs meant to serve community needs (Harper, Alkon, Shattuck, HoltGiménez, \& Lambrick, 2009). FPCs are found mostly at the local level and organized around a shared belief that the current conventional food system does not address needs in their communities. Local needs include methods to address hunger, diet-related disease and malnutrition, environmental pollution, lack of access to healthy food, and the loss of local small and midsize farms. FPCs also share the belief that these impacts are all interrelated and, therefore, solutions need to be systems oriented (Scherb et al., 2012).

Despite the fact that many of these groups go by the title of food 'policy' councils, they tend to focus more on projects (e.g., increasing physical access to healthy and/or local food) and local market engagement (e.g., development of farmers markets) than on policy and political engagement

1 FPCs go by other names, such as 'coalitions,' 'collaboratives,' and 'networks.' For the purposes of this paper, they will be referred to as food policy councils. See Sussman and Bassarab (2017) for the latest census of FPCs.
(Goddeeris, 2013; Scherb et al., 2012; Schiff, 2008). However, Sussman and Bassarab (2017) note that the interest of councils in the role that government has to play in addressing food system problems and, therefore, policy is increasing. Reasons for a lack of policy-oriented engagement could be due to the nascent nature of local food policy. Another reason could be what Eliasoph (1997) terms the 'culture of political avoidance,' which reflects the combination of people's sense of powerlessness when facing complex and large issues, a need to concretely make any change (no matter how small), and a belief that political talk does not accomplish anything. Political avoidance is embedded in a culture that avoids disagreements and focuses on individualism. Facing the conventional food system and its set of complex and global problems and local impacts could lead to less efficacy and agency for groups that focus on problems in the food system. Finally, previous research has found that some councils cite difficulties in defining policy priorities, lack of leadership, not being allowed to work on policy as a result of their government affiliation, or simply not being interested, as reasons that they are not engaged in policy (Scherb et al., 2012; Schiff, 2008).

In light of these considerations, how might members of FPCs, who share beliefs on community betterment, see their work in policy terms and thereby build local governance capacity? The advocacy coalition framework (ACF) provides one approach to thinking about an FPC's policy readiness, by providing an evidenced-based set of characteristics that a coalition should embody to be 'policy ready.' If FPCs do not embody these characteristics, then actions aimed at gaining these characteristics have the potential of increasing the efficacy and agency of FPC members, thereby increasing the coalition's policy readiness and broader local governance capacity in a new policy area.

This article presents a case study of an FPC that used a policy audit to increase its policy readiness. Because the FPC became policy ready, local governance capacity was increased, meaning that governmental and nongovernmental actors, collectively, were able set a policy agenda and begin creating a policy environment to address local 
needs. I applied the ACF to the case after the fact to explain how the audit increased the FPC's policy readiness by enabling the characteristics of an advocacy coalition. By applying the ACF to this case, the lessons learned are not just about a single case but are based on an evidence-based framework that can be used elsewhere to both evaluate an FPC as an advocacy coalition and develop an action plan for increasing policy readiness. From a practical standpoint, I further the discussion about the utility of a local food policy audit (O'Brien \& Denckla Cobb, 2012). Finally, published research on FPCs is limited and there is little evaluation of the role of FPCs that intend to affect policy in the policy process (Chen, Clayton, \& Palmer, 2015; Scherb et al., 2012).

In the next section I provide literature that outlines the ACF, grounding the reader in the policy process used to explain the case and the common characteristics of an advocacy coalition. Following, I offer my research objectives and methods, and then review the case. I then provide a background of the food policy audit and audit process. I finish by discussing the case in light of the ACF as an organizing construct and the role of the food policy audit in transforming the FPC to an advocacy coalition, and then offer a conclusion.

\section{The Advocacy Coalition Framework}

The ACF is an evidence-based framework designed to provide a shared set of concepts and language to describe and explain the policy process (JenkinsSmith, Nohrstedt, Weible, \& Sabatier, 2014). In policy studies, the ACF is but one way of framing the policy process; this framework is particularly useful to study FPCs that are developed via grassroots initiatives (versus a government-appointed or legislated council), but may have some relationship with government (e.g., local government holds a seat or supports the council in another way) for reasons explained below. The central reason is that the ACF works to examine coalitions of diverse actors (from both the public and private sector) organized around their beliefs on what should be.

According to the ACF, in a complex policy world, policy change happens in issue-specific networks that share a domain of expertise and are geographically bounded (Sabatier \& Jenkins-Smith,
2007). They are pervasive in government because elected officials devolve policymaking responsibility to bureaucrats who, in turn, consult routinely with a range of actors. Therefore, these issuespecific networks include a variety of actors beyond those that make policy, including community members, nonprofits, researchers, and the media (Sabatier \& Weible, 2007). In this way, the ACF lends itself to analyzing development of new local policy arenas where government, local institutions, private businesses, and community organizations are interacting to address local needs.

According to the ACF, the actors in local issue-specific networks are organized into advocacy coalitions. For example, a coalition could organize itself within a community to move smart growth policy forward in that specific locale. Often, with issue areas that have been around for a long period, other coalitions will form. With this example, one could imagine an anti-regulation, pro-development coalition organizing to counter the smart growth coalition. According to the ACF, people who are part of these advocacy coalitions have the greatest ability to make consistent change because they can more effectively participate in policy development in specific issue areas and, according to the framework, there are common characteristics that a group embodies when it is considered an advocacy coalition. Further, advocacy coalitions can be built from existing groups (Kübler, 2001). In this way, the ACF provides a set of characteristics that an already formed group, such as an FPC, could use to be policy ready (Sabatier \& Jenkins-Smith, 1999; Weible \& Sabatier, 2006).

Advocacy coalition members meet frequently and coordinate activities. Coalitions include actors from a variety of sectors and interests (e.g., legislators, agency staff, researchers, community members, journalists) who share normative core beliefs (Sabatier, 1988). In this way, the concept of an advocacy coalition fits well with grassroots, multisector FPCs. FPCs reflect a collection of interests from a variety of sectors (versus groups representing a singular interest or a singular sector that advocates). Also, the mission of grassrootsorganized FPCs are typically built on normative beliefs about how the food system should function and that functionality should be realized through 
democratic efforts. The success of advocacy coalitions relies on their ability to translate their beliefs into specific policies (Weible \& Sabatier, 2006) and their capacity to prioritize and mobilize the resources to make policy change (Elgin \& Weible, 2013).

Advocacy coalitions use technical information in developing their policy agendas. Because core beliefs are central to these coalitions, beliefs become the filter through which technical information is selected and understood. Therefore, acquiring new knowledge is gained through learning that is framed by beliefs (May, 1992; Sabatier, 1988). Information that contributes to learning is not introduced from the outside but from within the coalition, and it becomes a strategic resource used to establish and grow the coalition, convince decision-makers to support goals, and sway opinion. The ACF was developed, in part, to provide a more prominent role for technical information and the researcher in the policy process (Weible, Sabatier, \& McQueen, 2009). Researchers from agencies, think tanks, and universities (which are not often considered to be part of advocacy groups), therefore, can play a role in problem definition, evaluation of impacts, and solution development; these actors are members of the advocacy coalition who share policy beliefs (Sabatier \& Zafonte, 1999; Weible \& Sabatier, 2005).

In practice, the ACF has been suggested as an organizing construct to develop advocacy efforts of coalitions for policy change, particularly when a strong group of allies has a common goal or when a sympathetic decision-maker is in office who might respond to technical information provided by the coalition (Stachowiak, 2013). In this way, an FPC can be influential if it has the sympathetic ear of a local elected leader and has a policy request that can be backed up by technical information the group develops. Mendes (2008) suggests that new policy issue areas require civil society groups to facilitate governance and build capacity for governments. As such, the ACF has been used by researchers to facilitate coalitions in new policy areas and build the capacity of community coalitions. For example, researchers Cornelia and Jan Flora tailored the ACF to develop the 'Adaptation
Coalition Framework' as a community-based participatory action tool and action frame (Ashwill, Flora, \& Flora, 2011). The Adaptation Coalition Framework was then used to increase local coalition capacity to address climate change (Ashwill, Flora, \& Flora, 2011). Working with coalitions in two dozen communities across Latin America, they used the adapted framework to train community groups in the knowledge and organizational tools and a coalition-building strategy to manage climate change over the long term. As part of the strategy, community members engaged technical experts and international nongovernmental organization (NGO) representatives for enhanced technical assistance. The Floras found success in creating new local climate change coalitions and policy spaces focused on agenda-setting through planning efforts and mobilizing resources.

\section{Research Objectives and Methods}

The purpose of this research is to articulate the process by which local governance capacity in a new policy issue area was increased, as evidenced by the policy readiness of a cross-sector coalition. The Advocacy Coalition Framework describes advocacy coalitions that engage in the policy process as having common characteristics. FPCs, particularly grassroots FPCs that are formed around shared beliefs, can be examined using these characteristics to determine their policy readiness. Following the previous literature review, the characteristics that an FPC should possess to be an advocacy coalition ready to effectively engage in the policy process are the following 2 : (1) The issue area contains at least one coalition aiming to make policy change (2) that is a broad network (3) with a set of beliefs; and (4) these beliefs have been translated into specific strategies; (5) members are knowledgeable and are engaged with specialists; (6) technical information is in hand and used to do such things as determine current conditions, attract

\footnotetext{
2 The focus on advocacy coalitions and the ACF does not preclude other means by which groups can engage in the policy process. Rather, the ACF is an organizing construct that enables the policy readiness of an FPC to be systematically analyzed in relation to other, similar cases of belief-based coalitions.
} 
other members, determine policy positions, convince local officials to support issues, and outline next steps; and (7) activity is coordinated (and policy-oriented).

I use a case study approach, which is a common approach to answering policy process questions that involve networks, such as coalitions (Berry et al., 2004). The research objectives include tracing the development of a local FPC, describing the creation and utilization of the technical tool that translated beliefs into a policy agenda (a food policy audit), documenting initial impacts of the audit tool development process, and describing how the audit enabled a local FPC to exhibit the characteristics of an advocacy coalition.

The case presented here is of the Franklin County Local Food Council (FCLFC), which participated in a community-based research (CBR) project with the author. $\mathrm{CBR}$ is a collaboration between community-based organizations and researchers to develop research questions, apply shared research tools, and develop common assessments as a way to ensure more connected scholarship. As such, researchers who use CBR (and the many subtypes of CBR) get involved directly with the community (Blay-Palmer, Landman, Knezevic, \& Hayhurst, 2013; Mount et al., 2013). Beyond a general case study, methods utilized are participant observation and document analysis. I am both a researcher and a participant in the FCLFC, having been a member since its inception in 2011. I have attended and participated in over four dozen full council meetings, nearly 20 policy working group meetings, and several public events and one-on-one briefings with elected leaders. I was an advisor to the student intern who conducted the food policy audit.

The document analysis included three-and-ahalf years of full council and policy working group meeting minutes, member applications, administrative documents, and the policy audit itself. To address construct validity, an active member on the executive committee of the FPC read a final draft of the article. In addition, the student intern, who was the central figure conducting the policy audit, read the final draft as well. If there was disagreement, we decided that it would be noted in the text (Yin, 2003). There were no disagreements, but the intern and executive committee member were able to provide additional insights and clarifications. To address internal validity, I use the ACF as a guiding framework to examine the local food policy process.

\section{The Case: Franklin County Local Food Council}

Franklin County, Ohio, is home to the capital city, Columbus. The population of the county is just over 1.2 million, and the population of Columbus is a little over 800,000 (U.S. Census Bureau, 2015). In late 2009, planners from a regional planning commission, the Mid-Ohio Regional Planning Commission (MORPC), obtained funding from a local community foundation to conduct a food assessment and plan (MORPCp, 2010). To do this work the planners organized a 12-county working group of members drawn from the region, including public agency staff (planners, economic developers, public health professionals), nonprofit social services, food distributors and retailers, and a local nonprofit focused on food system change. Under the working group, other community members participated via task forces, including a food bank, gardening groups, urban grower groups, a local farm bureau, an organic growers group, Cooperative Extension, food-related businesses, and other local government officials.

The MORPC working group and task forces conducted their work with the purposes of (1) increasing access to fresh, healthful, safe, and locally produced food; (2) strengthening the regional food economy; (3) increasing viability by increasing profitability; and (4) illustrating the value to local decision-makers and their staff of coordinating with statewide food policy efforts and encouraging policies to allow agriculture on underused and vacant lands. They developed 24 recommendations, including recommendations to "ensure government support for local-food efforts" (MORPC, 2010, p. 38) and to conduct a food policy audit. The regional assessment and plan was not adopted by any local governments, and no one group or agency was identified to implement the plan. Instead, the working group included a recommendation to create local food policy councils in each of the 12 counties to implement this plan. 
MORPC fostered the development of county FPCs within its 12-county jurisdiction. Franklin County is the central county within this 12-county region. Over the summer of 2011, MORPC and members of its working group developed a selection committee ${ }^{3}$ and requested members of the public to apply to create a local FPC and be its members. Members were selected to represent a range of stakeholders (e.g., from all sectors of the food system, local governments, schools, universities, local food and hunger-oriented nonprofits, health professionals). In September 2011, selected farmers, representatives of local nonprofits, local agency staff (e.g., the city health department), local food business representatives (e.g., distribution, retailing), and educators agreed to create the FCLFC. Reviewing member applications, central themes emerged as to why people wanted to participate. Overall, people expressed a desire to make the community better and empower community members through the food system. People wrote about increasing the viability of local farmers, promoting small food businesses, addressing community members' health, and increasing access to good food. In their applications, they suggested that this work could not be done by a single person or organization but needed the organizing and coordinating effort of a coalition to aggregate resources, elevate voices, and bring attention to problems in the food system to create change. While the numbers on the council would fluctuate over time, it consistently maintained 14 to 19 voting members. There is no limit to how many nonvoting members can belong to the FCLFC, ${ }^{4}$ and it would increase from fewer than 10 to over 50 in the course of six years.

MORPC provided limited staff support for the FCLFC to schedule meetings and take notes. Beyond satisfying a recommendation of the regional food plan and assessment, the purpose of the council was to build an all-volunteer coalition

\footnotetext{
3 The author of this paper was not part of the selection committee.

4 Voting members are selected by current voting members via an application process. Nonvoting members are any community members who attend meetings and participate in the work of the council.
}

that was not associated with any single organization, government, or business, but rather was representative of both the community and the food system. Further, the purpose of the council was to coordinate and share resources, align food system change objectives, and develop synergies for greater impact.

Early on, meetings were spent establishing shared goals and values and developing administration procedures. A central belief of members was that creating a locally based food system would serve the community best. The mission of the group was "to expand, strengthen, and maintain a resilient and local food system in Franklin County and the surrounding area" ("About the Council," 2014). The group also established guiding principles, which included working toward community and regional prosperity and resilience, social justice and equity, and health and sustainability. The strategies that the FCLFC laid out to address their mission were (1) connect food and farm businesses, nonprofit organizations, and local government entities in a common effort to support a resilient local food system; (2) improve healthy food access, especially for low-income residents; (3) create and strengthen connections between farm and food businesses; and (4) educate citizens, agencies, organizations, and local businesses so that the food system is taken into account in planning and decision-making.

Notice that this FPC does not include 'policy' in its name. Even though the FCLFC is registered in the North American food council directory ${ }^{5}$ and was developed from a food policy council model, 'policy' was deliberately left out of the name of the coalition. While the vision of the MORPC plan was to have this group implement it, there was early debate about the role of policy, which started during the second meeting of this group. The debate centered around the greater importance of public education as a strategy for change over policy development, the potential of philanthropic foundations being leery of funding policy work, and that the agreed-upon problems the council was to

\footnotetext{
5 The Center for a Livable Future at Johns Hopkins conducts an annual census of food policy councils; see http://www.foodpolicynetworks.org/directory/
} 
work on were not policy-oriented but rather about practices and processes. As a result, policy action was set aside as a core function. During this debate, only three of the members voiced interest in paying attention to policy.

In mid-2012, a graduate student in rural sociology at Ohio State University became an intern at MORPC, ${ }^{6}$ working with the staff member who provided limited staffing support to the FCLFC. Aligning the interests of the intern, her advisor (the author of this article), and the broader recommendations of the regional plan and assessment, the intern developed a proposal to conduct an assessment for the council. She proposed her plan during the June 2012 council meeting, and a passing vote allowed her to move forward on behalf of the FCLFC. The assessment was a local food policy audit, and, as it was explained that assessments are a common first activity of food policy councils (Freedgood, Pierce-Quiñonez, \& Meter, 2011), this activity did not appear to council members as being politically oriented. An additional reason for the passing vote could be that the council had a culture of operating via consensus and avoiding disagreements. Also, the intern would be responsible for managing the audit process and, therefore, the burden of assessing the policy landscape would rest on her shoulders. The reason could also have had less to do with tension around political engagement and more about a 'culture of political avoidance' (Eliasoph, 1997, p. 605).

\section{Food Policy Audit: A Translational Tool (and Process)}

The earliest known guide to conducting a local food policy audit came from the Community Food Security Coalition and the California Sustainable Agriculture Working Group (Biehler, Fisher, Siedenburg, Winne, \& Zachary, 1999). The guide to conducting an audit, or 'inventory,' as these groups referred to it, provided readers with a primer on local agencies and departments and their potential role in the food system, including planning departments, Cooperative Extension, parks and recreation, law enforcement, transportation, public works, public health, human services, hous-

6 The intern became a council member in 2013. ing, and schools. The guide highlighted the role of local government and suggested that the inventory could be used to harness local government actors as allies, as what they do shapes the food system (e.g., where food is produced, distributed, retailed) and local governments have resources. By engaging local governments, particularly those that have not previously addressed local food policy, groups conducting the audit could build governance capacity.

A food policy audit can be considered a type of assessment. Assessments are "activities to systematically collect and disseminate information on selected community characteristics so that community leaders and agencies may devise appropriate strategies to improve their localities" (Pothukuchi, 2004 , p. 356). Assessments can play a role in prioritizing need and, therefore, agenda-setting, providing a path for next steps (Percy-Smith, 1996). While many food system assessments include policy change as an implicit or partial goal, the food policy audit is specifically designed to set a policy agenda to effect change throughout the food system by first assessing the policy landscape (O’Brien \& Denckla Cobb, 2012).

The food policy audit reflects a common assessment technique found in the 'smart growth' movement (Talen \& Knaap, 2003). Smart growth policy audits consist of determining the presence or absence of a list of policies. The policies are meant to reflect the community's smart growth priorities. A smart growth audit can be completed by community members with the help of city planners or other municipal staff (U.S. Environmental Protection Agency, n.d.). The intent of the 'scorecards' resulting from an audit was to create a far-reaching and democratized approach to community change.

The MORPC intern adapted, for the use of the FCLFC, an audit developed by faculty at the University of Virginia in 2009 (O'Brien \& Denckla Cobb, 2012). Similar to the process of a smart growth audit, the intern worked with community members (the FCLFC) and city planners and staff. She provided a draft of the adapted audit based on the mission of the FCLFC and its guiding principles (outlined earlier) to the FCLFC, MORPC, the Franklin County Economic Development and 
Planning department, and the Franklin County Office of Management and Budget. The final approved audit tool consisted of 100 policy topics phrased as yes/no questions. The items were divided into four broad categories and 18 subcategories. The four broad categories were Promoting Local Food, Sustainability, and Community Food Security; Addressing Public Health and Food Access; Strengthening Zoning and Land Use; and Fostering Social Equity. (See the Appendix for the list of 100 questions by category and subcategory in the policy audit.)

The process of conducting the audit was designed to be an intentional dialogue about local food system goals, perceived gaps, and potential opportunities. The dialogue serves the following two purposes: (1) It illustrates the roles of people and institutions across the county and gives them the opportunity to discuss these roles and how to coordinate and build on them (Mendes, 2008), and (2) it familiarizes people with the current landscape, which requires knowledge of local regulations, stakeholders, and local food policy goals. To familiarize the auditor with the policy landscape, we conducted document collection and research. Relevant information (plans, codes, and regulations) had to be gathered from across 11 departments and agencies. The aggregation of disparate information that potentially affected the mission of the FCLFC represented an important first step in identifying food policy gaps and opportunities.

The intern conducted the audit over the summer months of 2012 in consultation with the FCLFC, her MORPC supervisor, and her academic advisor. After document analysis and interviews with 13 county government staff and two representatives from local nonprofits, the county audit resulted in a score of 54 out of 100 . This means that 54 out of the 100 possible policies were present in the county. In late 2012, the FCLFC members prioritized the 46 policy opportunities to develop a final, ordered list of 11 policy priorities, which was then approved by a council vote. These priorities included a range of activities, from requesting that county elected officials sign a formal resolution that prioritizes elements of the council's mission, to evaluating the county's community gardening zoning regulation, to pro- viding economic development support to new farmers. Without much fanfare, the FCLFC set its policy agenda at the end of 2012, a little more than one year after it was formed. At the time of adoption, all original council voting members were still on the council and two new voting members had been added as a result of the auditing process. Following the adoption of the policy agenda, some attrition occurred. Because no members of the FCLFC followed up with the members who left, it is unclear if the attrition resulted from disagreement with the path the policy-oriented FCLFC was taking or other reasons.

A policy working group of the FCLFC was formed at the end of 2012 to take ownership of the audit on behalf of the greater council. The working group started with four members and grew to 14 by 2015 . One of the first activities of the working group was to set up briefings with county elected leaders. One of the members of the FCLFC is a county department staff person, who provided guidance on how to set up the briefings. The county commissioners, and particularly the president of the commission, were already sympathetic to local food and farm issues. The county commissioners had been working with staff on supporting community gardens, with projects focused on recent Somali immigrants, and they were using federal Community Development Block Grant (CDBG) dollars to fund healthy corner store projects in underserved neighborhoods. The president of the commission would continue regular briefings with the policy working group and chair of the council and would be considered part of the broader local food coalition.

During this first round of briefings in early 2013, the audit was presented along with the policy agenda. The council's first priority was a comprehensive resolution focusing on public health, ecological sustainability, and economic development objectives with regard to the local food system. The president of the commission was supportive and gained the support of the other two commissioners. The Franklin County Economic Development and Planning staff member, who is also a member of the council, drafted a resolution along with the other members of the council. In honor of National Food Day, the Franklin County 
commissioners passed Resolution No. 809-13 in support of the community's local food system. The resolution, in turn, laid the groundwork for the Franklin County commissioners to direct county planners and economic development staff to develop a local food system economic development plan for the county. The city of Columbus joined the planning effort, bringing in its health department and using a nonprofit group that is a member of the FCLFC as a consultant. The Local Food Action Plan was initiated in late November 2014, and the final plan was adopted in November 2016.

Subsequent discussions with the president of the commission's staff revealed that the commissioner's office was interested in another priority listed in the audit, namely to establish a program that doubles the purchasing ability of community members who use government benefits at farmers markets. The chair of the FCLFC at the time managed a farmers market. She worked with the policy working group to develop a "listening session" on this issue that took place in March 2014. The FCLFC brought together county farmers market managers, local funders, public health officials, and community members who work with low-income populations for a community dialogue about the interest and potential of establishing a double benefits program at farmers markets in the county. Prior to the listening session, members of the policy working group pulled together information on best practices and identified experts to be on a panel. Three dozen community members representing a variety of groups attended the event, which included short talks from the panelists and then a facilitated discussion between attendees and the panelists. The policy working group documented the conversation, surveyed participants' interest, and then conducted follow-up research and wrote a policy brief describing findings from the listening session, which was shared back to all attendees.

The listening session and follow-up with attendees had the unexpected result of growing the coalition and developing an agreement to move forward with establishing a pilot program. The brief was presented to the county commissioners and other potential funders, including the city of
Columbus leadership. In July 2014, county commissioners, along with the city of Columbus, funded a pilot program called "Veggie SNAPs." Because of the success of the listening session in growing the coalition and gaining support for initiatives, the listening session format would become a main strategy of the FCLFC. The FCLFC held two more listening sessions during 2014 and two in 2015, growing the coalition further by securing more nonvoting members.

The policy audit was revisited for strategic planning purposes in 2014 and early 2015. It was used to guide the FCLFC's involvement in the city and county's joint Local Food Action Plan. The FCLFC held listening sessions on different policy topics, bringing in more groups and developing recommendations that will feed in to the plan. In addition, given the broader networks built since the establishment of the FCLFC policy agenda, new policy issues have been brought to the attention of the council. For example, a non-FCLFC member group that is certainly a member of the broader coalition is keenly interested in policy to support a healthy corner store program. ${ }^{7}$ When the audit was being revisited, healthy retailing policy was not only added to the priorities, it made it to the top of the list. Healthy retailing policy is now on the FCLFC agenda as well as the agendas of several groups that are part of the broader coalition.

\section{Evaluating the Franklin County Local Food Council as an Advocacy Coalition}

The case of the FCLFC illustrates the transformation of a volunteer, cross-sector (private, nonprofit, and public), civically oriented coalition to a political actor organizing a new local policy issue area, thereby increasing the local governance capacity to address local problems in the food system. Following Kübler (2001), the FCLFC is a case of a micromobilization context, in that the coalition emerged from an established network and used informational resources available through the network to translate beliefs into action. The audit process created the setting for action and helped develop a

\footnotetext{
${ }^{7}$ See "Licensing for Lettuce" from ChangeLab Solutions for examples of these types of policies: http://changelabsolutions. org/publications/HFR-licensing-ord
} 
sense of political efficacy and policy readiness by building the policy analytical capacity of the FCLFC through the audit experience. Appling the Advocacy Coalition Framework, post-audit, helps to explain this transition. The audit process enabled the FCLFC to embody all the characteristics associated with an advocacy coalition.

First, the ACF assumes a broad network that includes actors from a variety of positions, sectors, and interests that share a core belief. The initial coalition included a limited number of members and no locally elected officials. The audit process was built around intentional conversation about the role of local government and other organizations in an ideal food system. This process identified sympathetic decision-makers and agency staff. Further, the audit process prioritized policy issues, creating an agenda that led to community listening sessions. Listening sessions identified people and groups with similar policy priorities, further expanding the coalition. Because the audit and the resultant policy agenda of the FCLFC was based on the beliefs of the FCLFC, all the coalition development with other groups was premised on shared beliefs and a common set of issues.

Another common characteristic of an advocacy coalition is that coalition members are knowledgeable and engaged with specialists. Knowledge and knowledge utilization can play an important role in the policy process and can affect policy initiatives (Radaelli, 1995). The auditor facilitated knowledge creation between a range of actors, including the FCLFC, elected officials, and the actors interviewed. Further, specialists were identified and engaged in the process through the listening sessions. A related characteristic of advocacy coalitions is that technical information is utilized to determine current conditions, attract other coalition members, determine policy positions, convince local officials to support issues, and outline next steps. The audit process resulted in a prioritized list of policies that was given to elected officials during briefings and to potential coalition members, and recently guided FCLFC strategic planning and engagement in the joint city and county Local Food Action Plan process.

The ACF assumes that the core beliefs of a coalition's policy have been translated to specific requests and that coalition members consider themselves to be working on policy change. Many of the FCLFC members are people who normally do not work on policy. The council had an agreedupon mission of focusing on localizing the food system to address perceived problems in the food system. When the FCLFC was created, policy was not included in its name and early discussions emphasized that policy would not be the focus. What resulted from the audit, then, was how to realize the coalition's mission (beliefs) via specific policies; in essence, the experience with information became a form of empowerment. What seemed at first to be an aversion to policy and political engagement was likely an apprehension to work in an arena in which council members could not envision the utility of policy initiatives given their mission, their own efficacy, and, therefore, their own agency (Eliasoph, 1997).

Further, the policy agenda was not about individual needs but reflected the shared mission of the coalition. The audit translated the mission and principles to core policy beliefs and then to specific policy initiatives. Not all council members agree on every individual policy point on the overall agenda, but all subscribe to the broader mission. The audit built the capacity of the coalition and its political efficacy. Understanding how the mission of the FCLFC translated into a desired policy environment allowed the council to build the necessary coalition around policy requests to actualize access to resources and eventual policy change.

Finally, the ACF assumes that activities of the coalition are coordinated and policy-oriented. Even prior to the audit, the FCLFC was meeting regularly with the aim of coordinating and sharing resources, aligning food system change objectives, and developing synergies for greater impact. However, the early FCLFC efforts were not explicitly policy-oriented. Since the audit, the FCLFC has continued to meet regularly and now coordinates with the broader coalition on policy initiatives. Because the FCLFC members know their agenda, it can easily be integrated into other areas. The example given earlier was healthy retailing policy.

It is important to note that food policy in Franklin County is a nascent policy area. As such, there are not multiple, competing coalitions opera- 
ting in this space. The FCLFC and other coalition members have had little conflict, working via consensus likely because this is a new and very niche policy area. As food policy continues to be a focus of the FCLFC, elected leaders, and the broader community, there will likely be other coalitions that form in this space, and conflict will likely enter the process. Further, as the food movement grows, the FCLFC will likely connect to efforts already operating at other scales.

Despite the opportunities that a policy audit process poses, it is not without its limitations. This case looked at the audit as a process of coalition transformation, not as the static output of the current audit process. Any one-time assessment is dated the moment it is complete. As food policy is a changing landscape, how does the work of the audit "live"? It was pointed out during the policy working group's January 2015 monthly meeting that some of the audit policy priorities are out of date, yet no one on the working group currently has the time to update those priorities and reassess the policy landscape. As the coalition grows, new members will need to be introduced to the audit process of translating beliefs into policy requests. This process will need to be taken on as a regular course of action. Perhaps the greatest limitation of the food policy audit is that it merely identifies what policies do and do not exist in the current policy environment that align with the coalition's mission. The coalition still needs to address whether a particular policy approach is the right one. An audit can act as a guide to local agendasetting but should not be mistaken for developing and assessing alternatives or as replacing the needed evaluation of policies once they are implemented to determine whether they are achieving policy objectives.

Another limitation is the capacity to conduct the audit in the first place. FPCs must have members or access to individuals via networks who have the time and expertise (or be willing to learn how) to do an audit. According to the ACF, generating technical information and overall learning is best conducted by members of the FPC or its broader network. For a low-capacity FPC, an audit could be conducted by an all-volunteer group using an existing audit as a place to start. Experts could be integrated by including them as interviewees during the audit process. However, the colearning of the policy environment would likely take much longer and could be taxing in terms of time and energy. If an FPC does not have the capacity to conduct an audit, there may be value in using the characteristics of an advocacy coalition as a generative discussion about the policy readiness of the group. This could be followed by developing strategies to embody the characteristics that the FPC does not already have.

Audits are not the only tools available for use by FPCs. The main obstacle that the FCLFC faced was not having translated its beliefs into a policy agenda, and the policy audit helped the FCLFC achieve the characteristics of an advocacy coalition. However, the audit was one part, albeit an instrumental part, of the larger case. Other tools may help an FPC become more policy ready. For example, a new tool called "Get it Toolgether: Assessing Your Food Council's Ability to Do Policy Work" could be used by an FPC to engage the group in a discussion about the policy process and evaluate group capacity (Palmer \& Calancie, 2017). The important point here, as was noted above, is that the FPC members participate directly in the learning process.

\section{Conclusion}

The case of the Franklin County Local Food Council illustrates how learning, framed by beliefs, became the mechanism for increasing governance capacity. Through a local policy audit, the FCLFC gained knowledge and efficacy to participate in the policy arena. In the end, the audit process established a new local policy area by identifying crosssector actors and organizations with which to build an advocacy coalition. In turn, this increased local governance capacity to create a local policy environment that enabled local needs to be met. The FCLFC participated in the translation of its mission and principles to policy information, which drew the parameters of the policy issue area and demonstrated where to focus attention. It is council members' experience with information that catalyzed change from a group that did not consider policy as an area of work to one that actively engaged in policy. This change was incremental 
and not radical, conducted through a consensusbased process.

Given that local food policy is an emerging policy area for local governments, local food policy councils are in a unique position. Generally, there are no "departments of food" in local government, and therefore food policy councils can play that coordinating role. Food policy councils create a space for civil society to participate in the policy process, providing balance in the food system between civil society, the state, and the market, and ultimately building local governance capacity. However, as a note of caution, when responsibility is devolved and shifted to nongovernmental actors, the organizational capacity of those actors does come into question. FPCs are underfunded (Sussman \& Bassarab, 2017), and this lack of capacity was noted for this case in the previous section. As such, the potential of FPCs to democratize the food policy process should not be considered a panacea for these reasons and others, such as FPCs not having the capacity to be inclusive by engaging community members most affected by policies (McCullagh, 2012).

The case of the FCLFC provides a promising action frame to increase governance capacity for budding coalitions aimed at addressing local needs in a new policy arena. The action frame includes (1) focusing on the characteristics of an advocacy coalition and (2) using a policy audit or other assessment tool to translate beliefs and aid in learning, which can enable the budding coalition to gain advocacy coalition characteristics and be policy ready. For the case of the FCLFC, policy readiness resulted in shared strategies, access to resources, and, ultimately, policy change.

\section{Acknowledgments}

I thank Caitlin Marquis, author of the local food policy audit, and Brian Estabrook, member of the Franklin County Local Food Council and its policy working group, for their willingness not only to be the subjects of this work, but to review it as well. Further, I want to recognize the hard work of all the council members. I feel very privileged to get to work with such a dedicated, collaborative group. I thank Samina Raja for sharing her ideas on policy readiness. I thank Patricia Strach and Shoshanah Inwood for providing excellent feedback on the draft manuscript.

\section{References}

About the Council. (2014). Retrieved from http://www.fclocalfoodcouncil.org/about-the-council/

Ashwill, M., Flora, C., \& Flora, J. (2011). Building community resilience to climate change: Testing the Adaptation Coalition

Framework in Latin America. Retrieved from World Bank website:

http:// siteresources.worldbank.org/EXTSOCIALDEVELOPMENT/Resources/2443621232059926563/5747581-1239131985528/Adaptation-Coalition-Framework-Latin-America web.pdf

Berry, F. S., Brower, R. S., Choi, S. O., Goa, W. X., Jang, H., Kwon, M., \& Word, J. (2004). Three traditions of network research: What the public management research agenda can learn from other research communities. Public Administration Review, 64(5), 539-552. http://dx.doi.org/10.1111/j.1540-6210.2004.00402.x

Biehler, D., Fisher, A., Siedenburg, K., Winne, M., \& Zachary, J. (1999). Getting food on the table: an action guide to local food policy. Retrieved from Alive by Nature website: http://alivebynature.com/GettingFoodOnThe'Table_pdf.pdf

Blay-Palmer, A., Landman, K., Knezevic, I., \& Hayhurst, R. (2013). Constructing resilient, transformative communities through sustainable "food hubs". Local Environment, 18(5), 521-528.

https://doi.org/10.1080/13549839.2013.797156

Chen, W., Clayton, M. L., \& Palmer, A. (2015). Community food security in the United States: A survey of the scientific literature (Vol. 2). Retrieved from Johns Hopkins Bloomberg School of Public Health website: http://www.jhsph.edu/research/centers-and-institutes/johns-hopkins-center-for-a-livablefuture/ pdf/research/clf reports/CFS-Lit-Review-II-final.pdf

Elgin, D. J., \& Weible, C. M. (2013). A stakeholder analysis of Colorado climate and energy issues using policy analytical capacity and the Advocacy Coalition Framework. Review of Policy Research, 30(1), 114-133.

http://dx.doi.org/10.1111/ropr.12005

Eliasoph, N. (1997). "Close to home": The work of avoiding politics. Theory and Society, 26(5), 605-647. http://dx.doi.org/10.1023/A:1006881913230 
Freedgood, J., Pierce-Quiñonez, M., \& Meter, K. A. (2011). Emerging assessment tools to inform food system planning. Journal of Agriculture, Food Systems, and Community Development, 2(1), 83-104. https://doi.org/10.5304/jafscd.2011.021.023

Goddeeris, L. (2013). Local government support for food systems: Themes and opportunities from national data. Retrieved from Michigan State University, Center for Regional Food Systems website: http:/ / foodsystems.msu.edu/uploads/files/local-govt-survey-brief.pdf

Harper, A., Alkon, A., Shattuck, A., Holt-Giménez, E., \& Lambrick, F. (2009). Food policy councils: Lessons learned. Retrieved from Food First website: https://foodfirst.org/publication/food-policy-councils-lessons-learned/

Jenkins-Smith, H. C., Nohrstedt, D., Weible, C. M., \& Sabatier, P. A. (2014). The Advocacy Coalition Framework: Foundations, evolution, and ongoing research. In P. A. Sabatier (Ed.), Theories of the policy process (3rd ed., pp. 183224). Boulder, Colorado: Westview Press.

Kübler, D. (2001). Understanding policy change with the advocacy coalition framework: An application to Swiss drug policy. Journal of European Public Policy, 8(4), 623-641. https://dx.doi.org/10.1080/13501760110064429

May, P. J. (1992). Policy learning and failure. Journal of Public Policy, 12(4), 331-354. https://doi.org/10.1017/S0143814X00005602

McCullagh, M. (2012). Food policy for all: Inclusion of diverse community residents on food policy councils (Master's thesis). Retrieved from http://hdl.handle.net/10427/011446

Mendes, W. (2008). Implementing social and environmental policies in cities: The case of food policy in Vancouver, Canada. International Journal of Urban and Regional Research, 32(4), 942-967. https://doi.org/10.1111/j.14682427.2008.00814.x

Mid-Ohio Regional Planning Commission. (2010). Central Obio local food assessment and plan. Retrieved from the Farmland Information Center website: http://www.farmlandinfo.org/central-ohio-local-food-assessment-and-plan

Mount, P., Hazen, S., Holmes, S., Fraser, E., Winson, A., Knezevic, I., . . Landman, K. (2013). Barriers to the local food movement: Ontario's community food projects and the capacity for convergence. Local Environment, 18(5), $592-605$. https://doi.org/10.1080/13549839.2013.788492

O’Brien, J., \& Denckla Cobb, T. (2012). The Food Policy Audit: A new tool for community food system planning. Journal of Agriculture, Food Systems, and Community Development, 2(3), 177-191. https://doi.org/10.5304/jafscd.2012.023.002

Palmer, A., \& Calancie, L. (2017). Get it toolgether: Assessing your food council's ability to do policy work. Retrieved from Food Policy Networks website: http://www.foodpolicynetworks.org/ pdf/FPN Toolkit 0531 17.pdf

Percy-Smith, J. (1996). Needs assessments in public policy. Bristol, Philadelphia: Open University Press.

Pothukuchi, K. (2004). Community food assessment: A first step in planning for community food security. Journal of Planning Education and Research, 23(4), 356-377.

Radaelli, C. M. (1995). The role of knowledge in the policy process. Journal of European Public Policy, 2(2), 159-183. https://doi.org/10.1080/13501769508406981

Renting, H., Schermer, M., \& Rossi, A. (2012). Building food democracy: Exploring civic food networks and newly emerging forms of food citizenship. International Journal of Sociology of Agriculture \& Food, 19(3), 289-307. Retrieved from http://www.ijsaf.org/contents/19-3/renting/index.html

Sabatier, P. A. (1988). An advocacy coalition framework of policy change and the role of policy-oriented learning therein. Policy Sciences, 21(2-3), 129-168. Retrieved from https://link.springer.com/article/10.1007/BF00136406

Sabatier, P. A., \& Jenkins-Smith, H. C. (1999). The Advocacy Coalition Framework: An assessment. In P. A. Sabatier (Ed.), Theories of the policy process (1st ed., pp. 117-166). Boulder, Colorado: Westview Press.

Sabatier, P. A., \& Weible, C. M. (2007). The Advocacy Coalition Framework: Innovations and clarifications. In P. A. Sabatier (Ed.), Theories of the policy process (2nd ed., pp. 189-222). Boulder, Colorado: Westview Press.

Sabatier, P. A., \& Zafonte, M. (1999). Are bureaucrats and scientists members of advocacy coalitions? Evidence from an intergovernmental water policy subsystem. Retrieved from UC-Davis website: http://www.des.ucdavis.edu/Faculty/Sabatier/SabatierZafonte1997.pdf

Scherb, A., Palmer, A., Frattaroli, S., \& Pollack, K. (2012). Exploring food system policy: A survey of food policy councils in the United States. Journal of Agriculture, Food Systems, and Community Development, 2(4), 3-14. https://doi.org/10.5304/jafscd.2012.024.007 
Schiff, R. (2008). The role of food policy councils in developing sustainable food systems. Journal of Hunger \& Environmental Nutrition, 3(2/3), 206-228. http://dx.doi.org/10.1080/19320240802244017

Stachowiak, S. (2013). Pathways for change: 10 theories to inform advocacy and policy change efforts. Retrieved from Center for Evaluation Innovation website: http://www.evaluationinnovation.org/publications/pathways-change-10-theoriesinform-advocacy-and-policy-change-efforts

Sussman, L., \& Bassarab, K. (2017). Food policy council report 2016. Retrieved from Johns Hopkins Bloomberg School of Public Health website: https://assets.jhsph.edu/clf/mod clfResource/doc/FPC\%20Report $\% 202016$ Final.pdf

Talen, E., \& Knaap, G. (2003). Legalizing smart growth: An empirical study of land use regulation in Illinois. Journal of Planning Education and Research, 22, 345-359. https://doi.org/10.1177/0739456X03022004002

U.S. Census Bureau. (2015). Population estimates 2014 [Table]. Retrieved from https://factfinder.census.gov/faces/tableservices/jsf/pages/productview.xhtml?src=bkmk

U.S. Environmental Protection Agency. (n.d.). Smart growth scorecards. Retrieved from http://www2.epa.gov/smartgrowth/smart-growth-scorecards

Weible, C. M., \& Sabatier, P. A. (2005). Comparing policy networks: Marine Protected Areas in California. Policy Studies Journal, 33(2), 181-201. http://dx.doi.org/10.1111/j.1541-0072.2005.00101.x

Weible, C. M., \& Sabatier, P. A. (2006). A guide to the Advocacy Coalition Framework. In F. Fischer, G. J. Miller, \& M. S. Sidney (Eds.), Handbook of public policy analysis: Theory, politics, and methods (pp. 123-136). Boca Raton, Florida: CRC Press.

Weible, C. M., Sabatier, P. A., \& McQueen, K. (2009). Themes and variations: Taking stock of the advocacy coalition framework. Policy Studies Journal, 37(1), 121-140. https://doi.org/10.1111/j.1541-0072.2008.00299.x

Yin, R. K. (2003). Case study research: Design and methods (3rd ed.). Thousand Oaks, California: Sage Publications. 


\section{Appendix.}

Franklin County Local Food Council Audit categories (1 $1^{\text {st }}$ tier, sub-categories $\left(2^{\text {nd }}\right.$ tier $)$ and yes/no questions ( $3^{\text {rd }}$ tier):

1) Promoting Local Food, Sustainability, and Community Food Security

a) Systemic Approaches

i) Does the locality support or participate in a Food Policy Council?

ii) Does the locality have a policy or goal to reduce its community environmental "foodprint"?

iii) Does the locality have a policy that its citizens have a "right to food security"?

iv) Does the locality have a declaration of food sovereignty?

b) Supporting sustainable agriculture

i) Does a policy or program exist to encourage transition to low-spray, sustainable, or organic agricultural methods, to reduce human and environmental exposure to potentially harmful chemicals?

ii) Is there a local policy or program that offers incentives to farmers to switch to more sustainable growing methods?

iii) Is there a local government policy or preference for local agencies to purchase low-spray, sustainably grown, or organic food?

iv) Does the locality have a policy, program, or goal to reduce nonpoint source pollution from agricultural operations?

v) Does the locality have a policy, goal or program to manage the harmful effects of animal manure?

vi) Does the locality support an organization or agency that can advise farmers on sustainable growing practices?

c) Encouraging production for local markets

i) Does the locality have a clear goal that supports the production and distribution of local food?

ii) Does the locality have economic development goals to support regional food production?

iii) Is there a support system to supply existing farmers with steady and seasonal farm labor?

iv) Are there local government or other programs to inspire and train new farmers, including assistance to immigrants who may come from farming families?

v) Is there a USDA-inspected community cannery, kitchen, or other processing facility open to local farmers, food entrepreneurs, and the public?

vi) Does the locality support an organization, agency, or individual who is able to provide farmers with technical assistance regarding financial solvency, and/or regulatory compliance?

d) Creating markets for local food

i) Does the locality publish or support a public guide to local food?

ii) Is there a local government policy recommendation for purchase of local food when available?

iii) Are there economic development programs, incentives or other tools for retailers to favor purchasing local food?

iv) Are there financial or other programs to support or incubate food-related businesses?

v) Does the locality have a policy to allow local farmers' markets or tailgate markets?

vi) Does the locality provide institutional support for local farmers' markets or tailgate markets?

vii) Is there economic development support for businesses that provide regional distribution of local food, such as a Food Hub?

viii) Does the locality provide tax incentives, leasing agreements, or other incentives to support development of businesses using locally produced food?

ix) Does the locality support, or are there programs for, mobile farm stands and food carts?

e) Making local food accessible to low-income populations

i) Does the locality support the purchase/use of Electronic Benefits Transfer (EBT) cards to provide low-income access to farmers' markets?

ii) Does the locality support the policy of $\$ 2$ or $\$ 3$ for every EBT dollar, when the EBT is used at grocery stores or market venues for fresh, local food? 
iii) Do farmers' markets and/or grocery stores accommodate WIC coupons, Senior Nutrition coupons, or EBT machines?

f) Emergency preparedness and food provisions

i) Does the locality have an emergency preparedness plan that includes contingency plans for shortterm interruptions of food deliveries?

ii) Does the locality support the provision of a central directory of all emergency food providers?

iii) Does the locality support coordination and cooperation among emergency food providers?

iv) Does the locality employ strategies for increasing food donations for emergency provisions and food banks?

v) Does the locality support a method, structure, or storage facility for donations of fresh foods to emergency providers?

g) Diverting and recycling food waste

i) Does the locality support a policy or program to divert a given percentage of bio-waste away from landfills?

ii) Does the locality support a compost pick-up program that processes food waste for recycling? Or does the locality provide another method of recycling/disposing of non-edible food waste?

iii) Does the locality allow for storage and pick-up of compostable items at commercial establishments?

iv) Does the locality support commercial composting or anaerobic digester facilities for food waste recycling?

v) Does zoning code allow community gardens to bring food waste from off-site sources for composting?

vi) Does the locality support educational programs encouraging backyard composting of food wastes?

vii) Does the locality support programs to encourage synergies for byproduct use among food producers and processors?

viii) Does the locality have a purchasing policy requiring that all disposable serviceware is compostable?

ix) Does the locality provide economic or tax incentives for establishment of facilities for processing/recycling food waste (composting, anaerobic digestion, etc.)?

$\mathrm{x}$ ) Does the locality's board or council include a solid waste management or planning professional?

xi) Does the locality support a program to redistribute viable uneaten food from commercial establishments to hungry, malnourished, or low-income populations?

2) Strengthening Zoning and Land Use

a) Urban agriculture on public land

i) Does the locality clearly allow the use of public space or land for nonprofit community food gardens?

ii) Is the locality currently employing or considering a "joint use" agreement to open the use of school land for food production (school gardens, community gardens, community urban farms)?

iii) Does the code allow for and support protection of open space for community gardens?

iv) Does the code allow for temporary and conditional use of abandoned lots for neighborhood gardens and/or urban farms?

v) Does the locality sponsor or work with an area community land trust or land bank in setting aside land for community or nonprofit gardens, or gardens where low-income residents can grow produce for sale?

vi) Does the locality minimize height restrictions on thru-way vegetation? If low vegetation is preferred, does the locality give preference to edible landscaping?

b) Urban agriculture on private land

i) Does the locality utilize zoning tools (such as overlays or subdistricts), or include language in the zoning code to support commercial urban agriculture operations on small plots and residential lands?

ii) Does the locality utilize zoning tools (such as overlays or subdistricts), or include language in the zoning code to support non-commercial community gardens on private lands?

iii) Does the locality allow for on-site sale of products by urban agriculture operations? 
iv) Do zoning codes pertaining to urban agriculture on private lands allow for construction of associated structures?

v) Does the locality support a program to facilitate soil testing on private lands for conversion to community gardens? Or does the locality require raised beds for community gardens?

vi) Are there funding streams for urban food production projects, such as Community Development Block Grants?

c) Home gardening and agricultural use of residential land

i) Does the zoning code allow small-scale beekeeping on residential land?

ii) Does the zoning code have language that supports residential "farm" animals: chickens, goats, roosters, etc.?

iii) Does the zoning code allow for the construction of structures associated with backyard agriculture?

iv) Does the zoning code minimize restrictions on lawn vegetation height?

v) Does the zoning code allow for the sale of homegrown produce on residential property?

vi) Does the zoning code allow for the sale of value-added products on residential property?

vii) Does the locality have limited restrictions on yard waste (compostables) in residential areas?

d) Traditional agriculture and rural land use

i) Are there regulations allowing flexibility for food producers to engage in minimal on-site processing?

ii) Does the zoning code allow for the sale of unprocessed farm products on agricultural lands?

iii) Does the zoning code allow for the sale of value-added products on agricultural lands?

iv) Does the locality offer working farmland tax incentives, such as agriculture/forested districts?

v) Does the locality have a policy or program (such as conservation easements) to support land conservation for food production?

vi) Are there creative leasing or financing models to reduce start-up farming debt?

vii) Does the locality have a map of its prime agricultural lands for conservation?

viii) Does the locality limit development potential in prime agricultural land through purchase of development rights, transfer of development rights, establishment of agricultural districts, or through other means?

3) Addressing Public Health and Food Access

a) Healthy food, wellness, and physical activity

i) Does the locality express a concern or goal for improving public health?

ii) Does the locality mention a goal to reduce obesity and/or chronic illness?

iii) Does the locality have an overall wellness plan?

b) Food offerings in schools and other public institutions

i) Does the locality clearly allow, support, or advocate for Farm to School (or similar) programs?

ii) Does the locality have other provisions for school purchasing of local or organic foods?

iii) Does the locality clearly have a policy to reduce availability of junk food in schools and other public buildings (e.g. vending machines and purchasing options)?

iv) Do the schools have a policy or program to educate cafeteria workers on preparation of fresh, local food and/or nutrient-rich food?

v) Is the locality clearly encouraging or supporting the inclusion of food-based lesson plans in schools?

vi) Does the locality clearly encourage and/or directly support establishment of school garden programs at all levels of $\mathrm{K}-12$ ?

c) Community education and empowerment

i) Does the locality encourage that chain restaurants provide consumers with calorie information on in-store menus and menu boards?

ii) Does the locality have a clear tax or other strategy to discourage consumption of foods and beverages with minimal nutritional value, such as sugar sweetened beverages?

iii) Does the locality have educational/promotional programs to discourage the use of Supplemental Nutrition Assistance Program (SNAP) benefits for sodas, high sugar, and low nutrient foods? 
iv) Does the locality develop media campaigns, utilizing multiple media channels (print, radio, internet, television, social networking, and other promotional materials) to promote healthy eating?

v) Are community members involved in the organization of markets or other food opportunities?

d) Transportation options for accessing food

i) Do safe biking and walking paths exist between neighborhoods and food stores and markets?

ii) Does the locality have a bus service that connects neighborhoods directly with food stores and markets, requiring no more than one bus change?

iii) Does the locality have a low-cost taxi or ride-sharing service that connects neighborhoods directly with food stores and markets?

iv) Are transportation services available in rural as well as urban areas?

v) Are transportation services available at multiple times of the day and evening?

vi) Does the locality have a bike path or sidewalk plan?

4) Fostering Social Equity

a) Food security for disadvantaged populations

i) Does the locality have a policy to provide access to quality food for all citizens, especially those with greater need?

ii) Has the locality done any infrastructure, transportation or other studies to identify issues of lowincome neighborhoods gaining access to quality food, in rural as well as urban areas?

iii) Does the locality have a policy or program to support stores that offer fresh produce, meats, dairy, and eggs to low-income populations?

iv) Does the locality have a system for directing/referring people in need of food to the places that can help?

b) Business incentives for low-income food access

i) Does the locality have an expedited development and/or permitting process for grocers that will provide healthy, local foods in underserved locations, in rural as well as urban areas?

ii) Are there any regulatory incentives, such as relaxed zoning requirements or tax credits, that can facilitate new stores in underserved areas?

iii) Does the locality offer any predevelopment assistance to developers to expedite the review process for grocery stores in underserved areas?

c) Equitable conditions for farm laborers

i) Does the locality support a living wage policy for all those who work, including migrant farm labor?

ii) Does the locality provide or ensure that training for farm workers is provided in a comfortable training environment, and that the training is adequate and in their native language, and that someone is available to answer farm worker questions in their own language? 